\title{
Hydrological Modeling of Upper OumErRabia Basin (Morocco), Comparative Study of the Event-Based and Continuous-Process HEC-HMS Model Methods
}

\author{
Mohamed Msaddek $^{1}$, George Kimbowa ${ }^{2,3,4^{*}}$, Abdelkader El Garouani $^{1}$ \\ ${ }^{1}$ Faculty of Sciences and Techniques, Sidi Mohamed Ben Abdellah University, Route Imouzzer, Fez, Morocco \\ ${ }^{2}$ Pan African University, Institute of Water and Energy Sciences (Including Climate Change), (PAUWES), C/o University \\ AbouBekrBelkaid, Tlemcen, Algeria \\ ${ }^{3}$ Faculty of Engineering, Busitema University, Tororo, Uganda \\ ${ }^{4}$ Wageningen University and Research, Water Resources Management Group, Wageningen, Netherlands \\ Email: simo.msaddek@gmail.com, „georg.kimb@gmail.com, el_garouani@yahoo.fr
}

How to cite this paper: Msaddek, M., Kimbowa, G. and El Garouani, A. (2020) Hydrological Modeling of Upper OumErRabia Basin (Morocco), Comparative Study of the Event-Based and Continuous-Process HEC-HMS Model Methods. Computational Water, Energy, and Environmental Engineering, 9, 159-184. https://doi.org/10.4236/cweee.2020.94011

Received: September 3, 2020

Accepted: October 18, 2020

Published: October 21, 2020

Copyright $\odot 2020$ by author(s) and Scientific Research Publishing Inc. This work is licensed under the Creative Commons Attribution International License (CC BY 4.0).

http://creativecommons.org/licenses/by/4.0/ (c) (i) Open Access

\begin{abstract}
Human population growth and land-use changes raise demand and competition for water resources. The Upper OumErRabia River Basin is experiencing high rangeland and matorral conversion to irrigated agricultural land expansion. Given Morocco's per capita water availability, River-basin hydrologic modelling could potentially bring together agricultural, water resources and conservation objectives. However, not everywhere have hydrological models considered events and continuous assessment of climatic data. In this study, HEC-HMS modelling approach is used to explore the event-based and continuous-process simulation of land-use and land cover change (LULCC) impact on water balance. The use of HEC-GeoHMS facilitated the digital data processing for coupling with the model. The basin's physical characteristics and the hydro-climatic data helped to generate a geospatial database for HEC-HMS model. We analyzed baseline and future scenario changes for the 1980-2016 period using the SCS Curve-Number and the Soil Moisture Accounting (SMA) loss methods. SMA was coupled with the Hargreaves evapotranspiration method. Model calibration focused on reproducing observed basin runoff hydrograph. To evaluate the model performance for both calibration and validation, the Coefficient of determination $\left(R^{2}\right)$, Nash-Sutcliffe efficiency (NSE), Root Mean Square Error (RSR) and Percent Bias (PBIAS) criteria were exploited. The average calibration NSE values were 0.740 and 0.585 for event-based (daily) and continuous-process (annual) respectively. The $\mathrm{R}^{2}$, RSR and PBIAS values were $0.624,0.634$ and +16.7 respectively. This
\end{abstract}


is rated as good performance besides the validation simulations were satisfactory for subsequent hydrologic analyses. We conclude that the basin's hydrologic response to positive and negative LULCC scenarios is significant both positive and negative scenarios. The study findings provide useful information for key stakeholders/decision-makers in water resources.

\section{Keywords}

HEC-HMS Model, Land-Use and Land Cover Change, Soil Moisture

Accounting (SMA), Upper OumErRabia Watershed

\section{Introduction}

Morocco like the most countries, experiences anthropogenic pressure and land-use dynamics particularly in and around mountainous basins [1] [2]. The interactions among land-uses, soil types, vegetation cover, climate variability and subsequent impact on hydrologic behaviors of watersheds have been studied by various researchers [3]-[9]. For the recent years, more people have settled around the OumErRabia (OER) due to favorable climate thus increasing the overall basin's population. This has consequently raised demand and competition for land, water and food resources [10] and thus leading to irrigated agriculture expansion. In the Upper OumErRabia River Basin (UOERRB), land-use and land cover change (LULCC) trends mainly involve the conversion of rangeland and matorral to irrigated agriculture and forestry. Land use and climate related studies done in Morocco for example [11]-[16] indicate a need for comprehensive mechanisms to conserve river waters and strategic planning to enable water availability for various competing uses. However, most recent land-use studies conducted in the OumErRabia (OER) basin are limited to water quality variation [17] and soil fertility impact [18].

The unsustainable land-use practice involving overgrazing, intense cultivation, over-exploitation of forests resources especially by the poor communities is pointedly shifting the hydrologic characteristics of the OUERRB. This has resulted in amplified runoff, erosion, sedimentation and degradation threatening the basin's water availability and reliability. The growing water demands, recurring and prolonged droughts associated with increasing climate variability and changing LULC are pointedly responsible for several water allocation challenges in the UOERRB [12]. Consequently, this has caused tension among water resources planning, developing and management authorities [19] towards allocation of the already scarce water resources among the increasing users [20] [21]. However, [22] noted limited or hardly any studies conducted to back up these insights.

The Morocco government and local authorities realize the disastrous impact of recurrent droughts on valued water resources. However, much of the government's effort has focused on sensitization of people about sustainable agri- 
cultural practices, water and related resources exploitation. The bearing of anthropogenic actions and climate variability studies is left less vibrant yet existing government policies are hardly implemented. According to an assessment study by [23], the distressing reduction in the basin's surface and ground water resources has been majorly linked to the regional climate variability in the previous decades. There is increased establishment of private wells within the watershed further adversely impacting the region's ground water resources. There is need for sustainable land-use and management plans and strategies especially at the moment when the OumErRabia Hydraulic Basin Agency locally known as l'Agence du Bassin Hydraulique de l'Oum-Er-Rbia (ABHOER) is extending irrigated area to fulfil the country's food demands and agricultural industries' raw materials needs. The ABHOER recognizes anticipated depletion of major available water resources owing to frequent droughts. However, the quantification of LULCC and impact-assessment of these processes on upstream river basin hydrology is still inadequate. The idea of hydrologic modelling [24] [25] [26] has been in use for quite time [24] [27] and is widely applied for instance in management of water resources [28], impact-assessment of LULCC and climate change on hydrology, water resource evaluation planning and allocation [16] [18] [29] [30] [31] [32] [33]. The HEC-HMS was selected for this study because it is a well-documented semi distributed hydrologic model flexible for both temporal and spatial scales and can be easily set-up and used with medium expertise [34]. Besides, the model usually requires less input calibration parameters.

In Morocco, HEC-HMS modeling approach has been used in recent studies such as [35]-[40]. Despite several national and regional studies evaluating hydrologic responses to LULCC and climate variability across the OER basin [9] [41], there is hardly any study that exclusively focuses on the UOERRB watershed accounting for local trends. Therefore, analyzing the impact of LULCC on hydrologic behavior of a watershed is vital for sustainable water resources management. Thus the objectives of the study were to: 1) explore and understand impact of land-use and land cover change (LULCC) on the water balance of the UOERRB using HEC-HMS-modelling approach; and 2) compare the performance of the event-based and continuous-process methods of the HEC-HMS model. We focus on the role of forests and agroforestry and the impacts of forest transition and forest degradation on the water availability in a case study area UOERRB.

\section{Materials and Methods}

\subsection{Study Area Description}

The OER River draining the middle Atlas and the north-western High Atlas [11] is a major source of hydroelectric power and irrigation for a significant population [42] and thus a key ecosystem to the Moroccan economy. The $550 \mathrm{~km}$ long main stream of the basin, covering $35,000 \mathrm{~km}^{2}$ of the surface, is an agriculturally 
rich region containing 50 percent of Morocco's public irrigated agriculture [23] [43]. Nevertheless, the study focused on the $1049 \mathrm{~km}^{2}$ UOERRB: a hydrological unit in the Middle Atlas with an equivalent length and perimeter of $119 \mathrm{~km}$ and $255 \mathrm{~km}$ respectively. The basin is located between latitude $33^{\circ}$ and $33^{\circ} 05^{\prime}$ North and longitude $5^{\circ} 01^{\prime}$ and $5^{\circ} 08^{\prime}$ West, with basin outlet located at the Tarhat weather station. This basin contributes to the large watershed drained by the OER River whose source is at an altitude of $1800 \mathrm{~m}, 47 \mathrm{~km}$ of the Khénifra city (Figure 1). Geologically, the basin major soil substrates include limestone and dolomites, with the eastern boundary of Khénifra constituting Triassic formations. The Khénifra essentially comprises sandstones chists attributed to the ordovician with the limestone and dolomites located on flushing levels on the slopes. In the valleys, are the triassic red clays, constituting places of intense ravines mostly in the Middle Atlas margin slopes [44] [45]. At the Atlas mountain side, the basin experiences a Mediterranean climate characterized with high temperatures in the summer and warm autumn. There is an increasing rainfall distribution from downstream zones to upstream Atlas mountainous areas with significant spatial variation within the basin. The UOERRB's average annual temperature and rainfall are $16.1^{\circ} \mathrm{C}$ and $600 \mathrm{~mm}$ respectively. The basin's mean minimum and maximum temperatures are $7{ }^{\circ} \mathrm{C}$ and $22^{\circ} \mathrm{C}$ respectively. The minimum and maximum precipitation is 295 and $1300 \mathrm{~mm}$ respectively, with

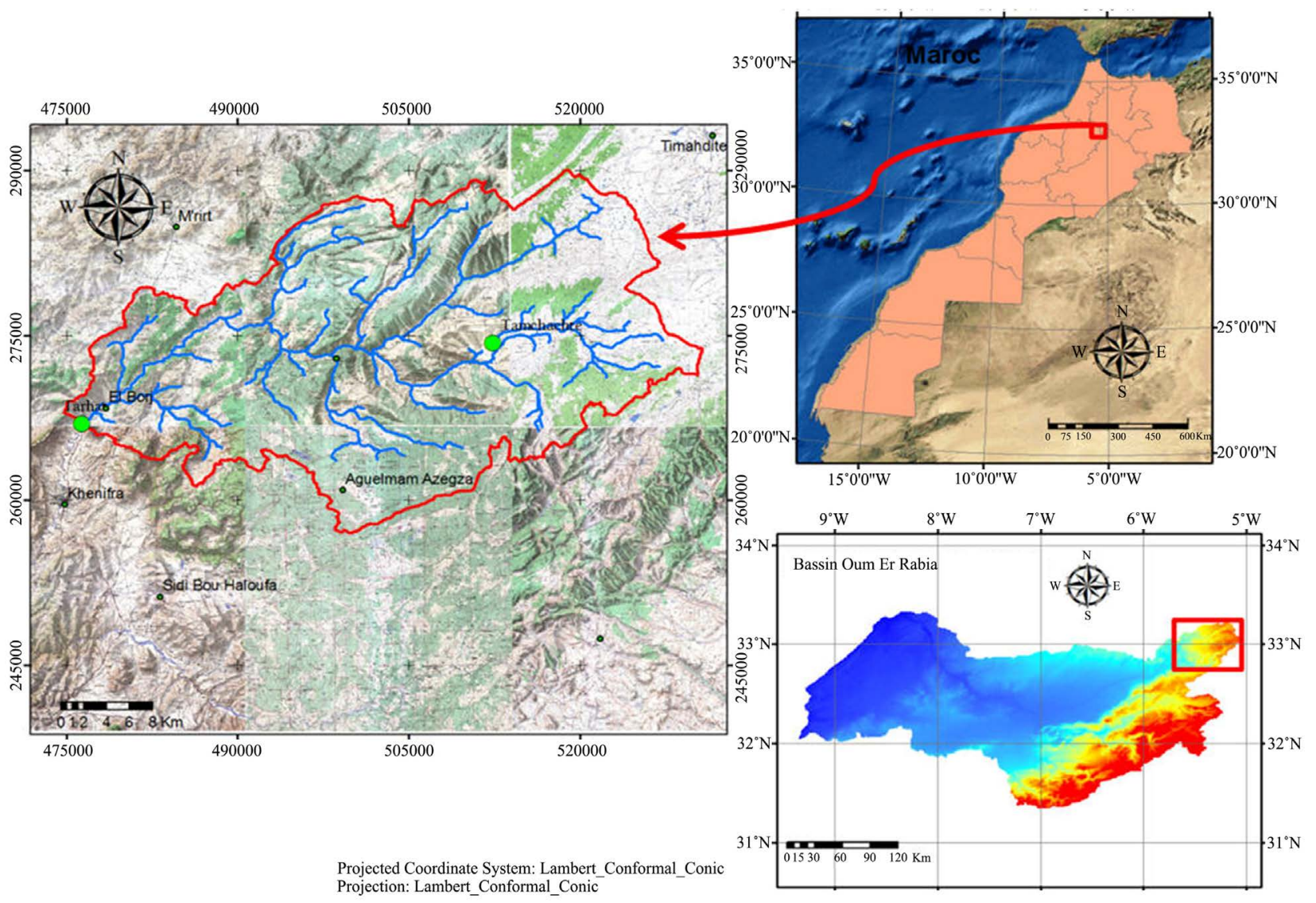

Figure 1. Location of upper oum er rabia river basin. 
October to May being the wettest months contributing about $85 \%$ of the total annual rainfall. The basin's vegetation cover is characterized by the presence of matorrals with a predominance of olive, orange orchards and forests. The forest cover is mostly concentrated at the basin downstream. The basin's main economic activity is agriculture in the plains and irrigated fields. The basin's topography varies from $2400 \mathrm{~m}$ in the upstream south to $864 \mathrm{~m}$ in the downstream north.

\subsection{Data, Collection and Analysis}

\subsubsection{HEC-HMS Model Inputs}

Daily mean rainfall and hourly discharge data for the two gauging stations of Tarhat and Tamchachte (Figure 2) were collected from the ABHOER. The watershed has limited number of gauging and weather stations. Weather data was required for SMA continuous simulation of the watershed stream flow. However, due to lack of observed measurements, the weather data used for this study was estimated by interpolation on measured climate data from the 4 weather stations across the study area obtained from Global Weather Data for SWAT. The data was partitioned into sets for testing, calibration and for validation. Table 1 presents the model input data sources and processing.

\subsubsection{Data Pre-Processing}

The 2016 LULC map was derived from Lands at satellite imagery data (https://earthexplorer.usgs.gov/) with $2.5 \mathrm{~m}$ resolution. The image was classified into seven classes by using Arc-GIS 10.3 and photo-interpretation method [46]. The major LULC in UOERRB (Table 2 and Figure 3 ) is forest, matorral, arable

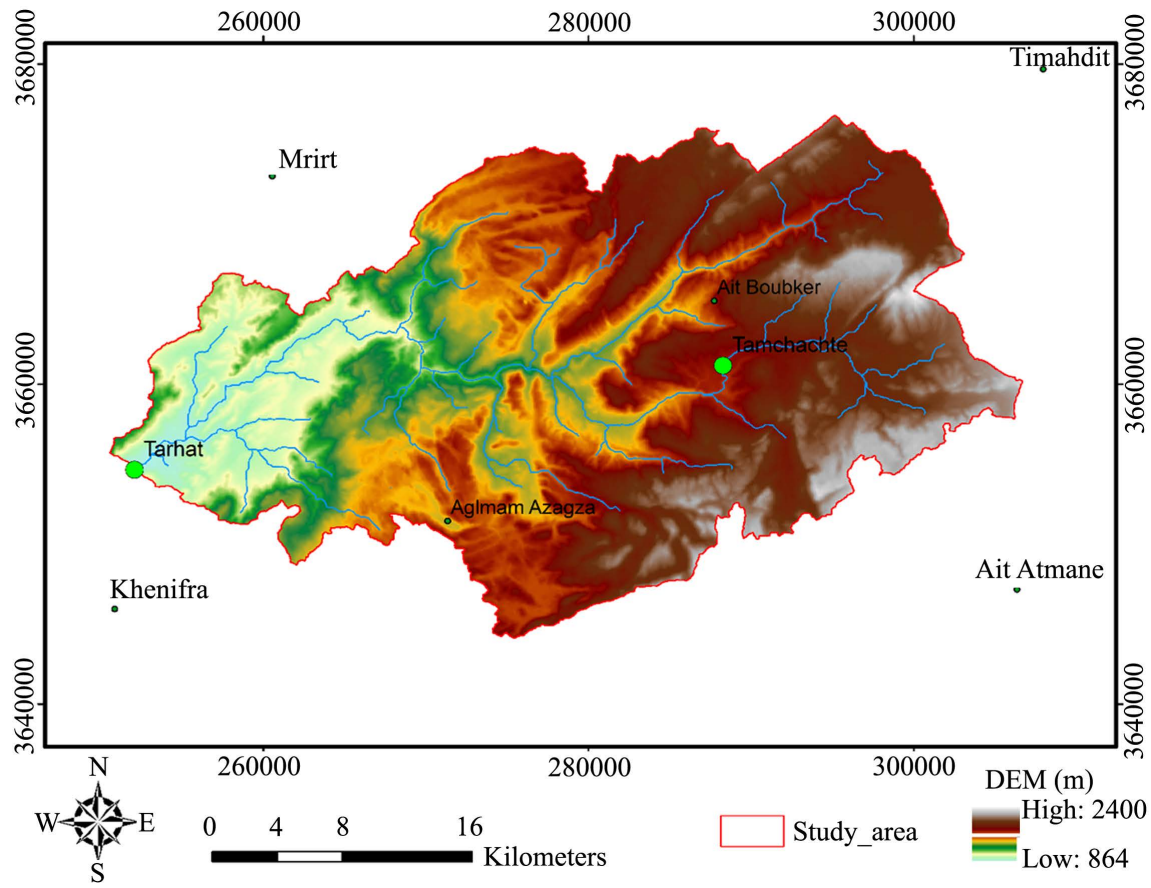

Figure 2. DEM of the UOERRB. 


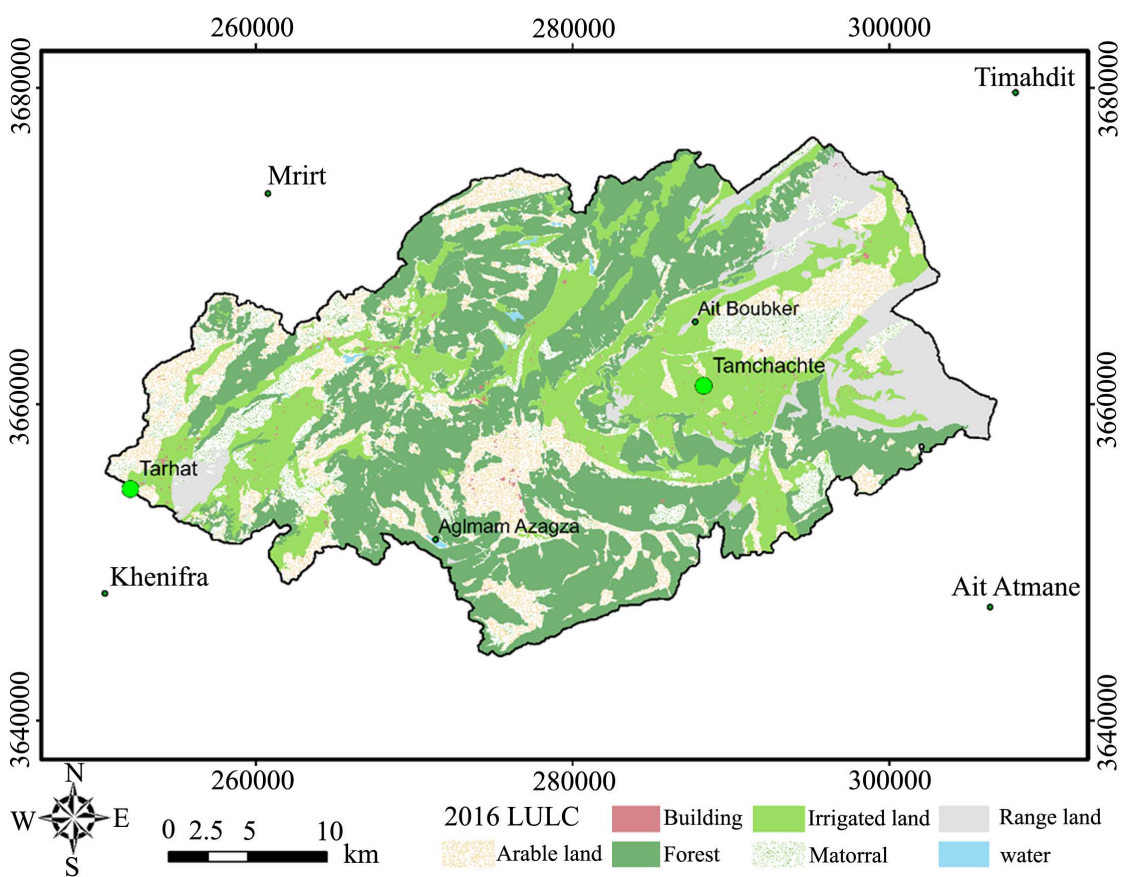

Figure 3. 2016 LULC map for the UOERRB.

Table 1. HEC-HMS model input data sources.

\begin{tabular}{|c|c|}
\hline Data type & Description (Source and Processing) \\
\hline Climate & Rainfall intensity from ABHOER, Morocco. \\
\hline Soils & $\begin{array}{l}\text { Digital data from National Institute of Agronomic Research } \\
\text { (Institut de La NationaleRecherrcheAgronomique), Pedology } \\
\text { Regional Labaratory, Meknes (Labaratoire Region de Pedologie), } \\
\text { Khenifra Rabat }\end{array}$ \\
\hline Hydrologic (Stream flow) & Historical data sets from ABHOER, Morocco \\
\hline Land use \& Topography & $\begin{array}{l}\text { Historical LU maps created/digitized from Lands at images } \\
\text { (2002 and 2016) \& DEM secured from USGS website. }\end{array}$ \\
\hline Weather data & $\begin{array}{l}\text { Interpolation on measured climate data from weather stations } \\
\text { across the study area obtained from Global Weather Data for SWAT }\end{array}$ \\
\hline
\end{tabular}

Table 2. Land-use classification in UOERRB.

\begin{tabular}{ccc}
\hline \multirow{2}{*}{ Land use } & \multicolumn{2}{c}{ Surface Area (2016) } \\
\cline { 2 - 3 } & $\mathbf{k m}^{\mathbf{2}}$ & Percentage \\
\hline Arable land & 194.68 & 18.5 \\
Building & 4.05 & 0.4 \\
Forest & 419.97 & 39.9 \\
Irrigated land & 254.24 & 24.1 \\
Matorral & 84.72 & 8.0 \\
Range land & 92.88 & 8.8 \\
Water & 2.39 & 0.2 \\
Total & 1052.93 & 100 \\
\hline
\end{tabular}


land and irrigated areas. The LULC and Hydrological Soil Group (HSG) maps were used to estimate the Curve Number (CN). The seven classes were later re-grouped into four classes for LULC change trend comparison and analysis with the 2002 LULC map. The basin area, river length, average slope value and $\mathrm{CN}$ were generated from HEC-GeoHMS.

The HSG map comprising of numerous soil textures was generated by digitizing from the pedological map of Khenifra region (Figure 4). From the two gauging stations of Tarhat and Tamchachte (Table 3), the daily rainfall and hourly streamflow data for periods of 1980-2015 and 1975-2011 respectively were collected. Weather data was obtained from the Global Weather Data for SWAT. The analysis of the hydro-climatic series involved checking, analysis and testing of the rainfall and hydrometric data. The precipitation and flow datasets are from Tamchachte (Upstream) and Tarhat (downstream). We consider a 35 hydrologic year precipitation records of 1980-2015. The analyses aimed at determining the hydro-climatic trends, extracting rainfall variability, and identifying the extreme rains expectedly resulting in the basin floods. From Figure 5, Tarhat and Tamchachte records, the wettest and driest months are November-February

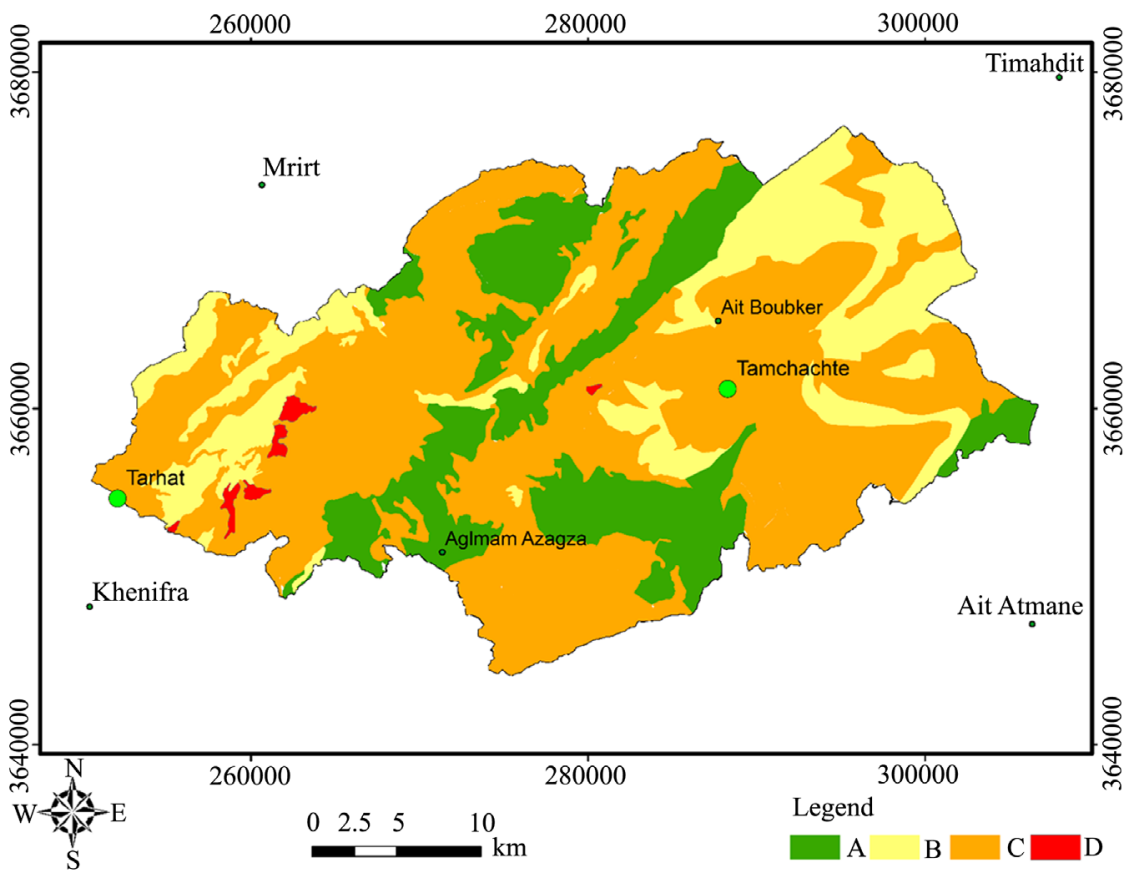

Figure 4. SCS-CN HSGs for UOERRB.

Table 3. Tarhat and Tamchachte locations.

\begin{tabular}{cccccccc}
\hline \multirow{2}{*}{ Stations } & \multirow{2}{*}{$\begin{array}{c}\text { Station } \\
\text { Reference }\end{array}$} & \multicolumn{3}{c}{ Coordinates (m) } & \multicolumn{2}{c}{ Measurement period } \\
\cline { 3 - 7 } & & $\mathrm{X}$ & $\mathrm{Y}$ & $\mathrm{Z}$ & Precipitation & Flow \\
\hline Tarhat & 4875 & 476,400 & 267,500 & 1036 & $1980-2015$ & $1975-2011$ \\
Tamchachte & 7708 & 512,330 & 274,340 & 1685 & $1980-2015$ & $1975-2011$ \\
\hline
\end{tabular}




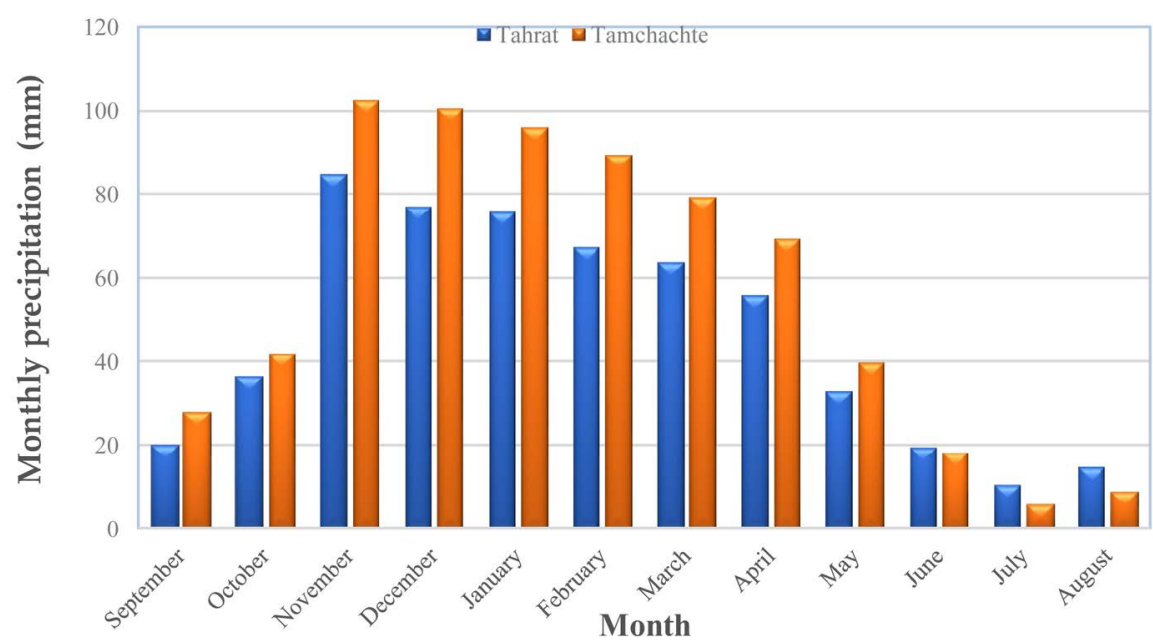

Figure 5. Tarhat and Tamchachte mean monthly precipitation, 1980-81 to 2014-15.

and June-August respectively. From both stations' records, significant rainfall amounts are recorded during the winter period. Precipitation distribution is determined by various factors with the Atlas mountain experiencing a cold sub-humid climate where some precipitation amounts are transformed into snow. The average annual rainfall was $679 \mathrm{~mm}$ and $557 \mathrm{~mm}$ for Tamchachte and Tarhat respectively.

\subsection{Methods}

The study is based on analysis of climate and stream flow data used for HEC-HMS model calibration and validation. Field visits were done to ascertain the current land use in the basin for the model setup. The major inputs for the HEC-HMS model included the DEM, soil data, land use and land management. The model was first calibrated and validated before simulating hydrologic processes scenarios. Multiple parameters were individually and manually adjusted (maximum-minimum) and the model was executed with identified reasonable ranges of the most sensitive parameters. Figure 6 illustrates detailed research study methodology. Land-use mapping aimed at better understanding the vegetation trends and evolution for the period 1980-2016. We conducted on-screen digitization of the 2016 Lands at satellite to generate the 2016 LULC map. To study the detailed LULC change in UOERRB, the 2016 LULC was then reclassified for assessment and comparison with the existing 2002 LULC map. We aimed at linking and comparing the trends of vegetation cover and flood hydrographs. GIS software was utilized for digitization, integration, overlay and presentation of the spatial and non-spatial data of LULC change. Limited field inspections were performed using Global Positioning System (GPS) to ascertain accurate location data points for specific LULC classes. The 2002 LULC map [47] was developed by the maximum likelihood supervised classification (MLC) method for time series of Lands at bands and vegetation-soil-water (VSW) index detailed in [48]. 


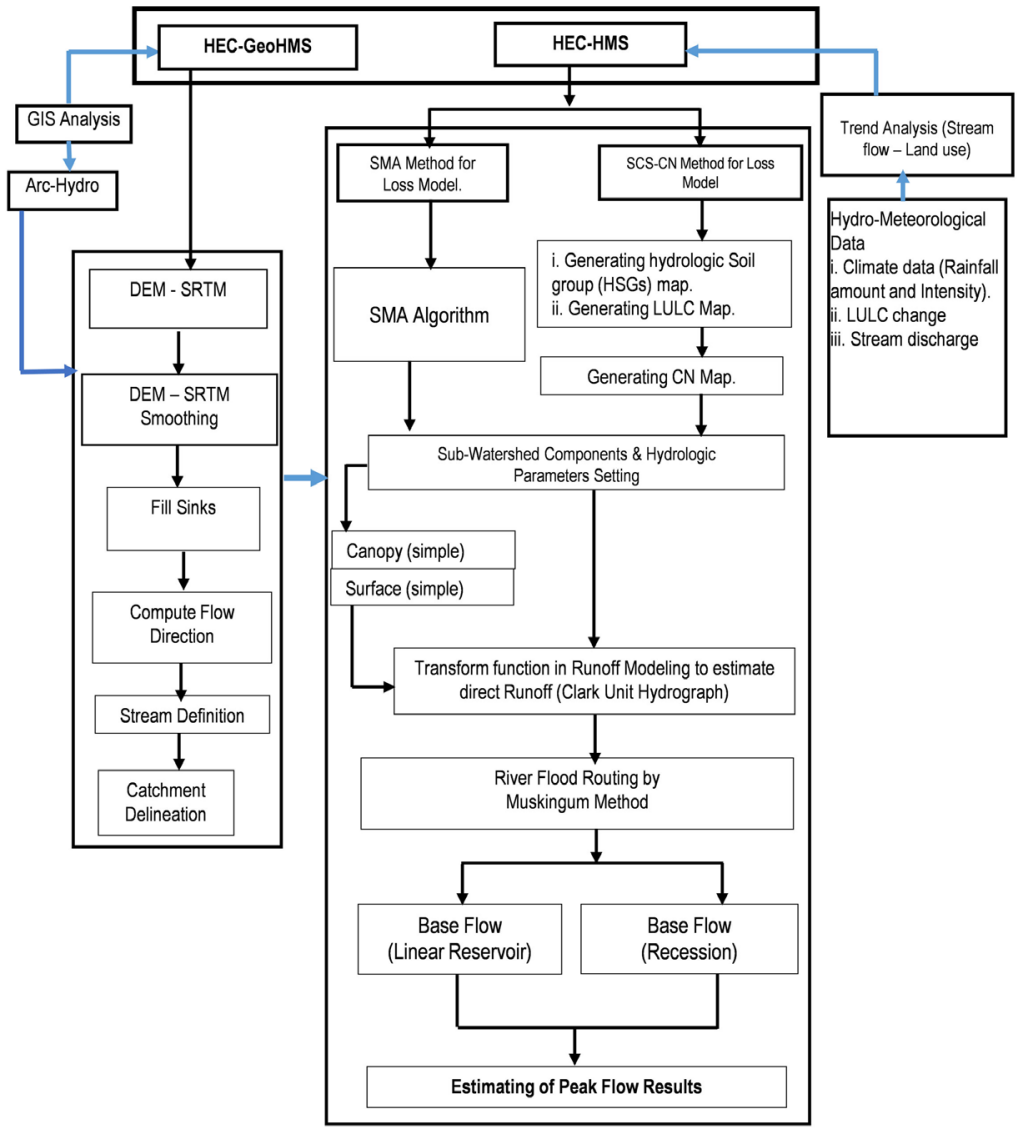

Figure 6. Study methodology.

\subsubsection{The Modules of the HEC-HMS Model}

The basin model (structural module of the basin) involves schematizing the catchment area in basic elements connected in form of a branched tree. HEC-HMS also known as Hydraulic Engineering Center-Hydrologic Modelling System is a development of the United States Army Corps of Engineers, designed to simulate the precipitation-runoff processes of watershed systems belonging to the famous HEC (HEC-RAS, HEC-GeoRAS, HEC-GeoHMS) [49] [50] [51]. The HEC-HMS offers the opportunity to represent all natural or artificial entities installed in a basin [50]. These elements influence the rainfall-flow transformation from sub-basins, outfalls to rivers and diversion water channels. The meteorological model's objective is to distribute the rainfall seized over whole study area. The HEC-HMS has seven different precipitation methods [52] for describing meteorology.

The methods include: Specified Hyetograph, the user is responsible for specifying time series data for sub-basins hyetograph at his disposal; Frequency Storm, is utilized in developing an event precipitation where the heights for different durations in the downpour have a coherent probability; Gages weights, weighted stations, uses a weighting coefficient for each precipitation measurement station; Inverse distance, applies the square inverse method of distances to compute the mean precipitation by assigning each station a weighting coeffi- 
cient; Gridded precipitations method, introduces the precipitation in form of a grid and is designed to work with Modclark gridded transform; Standard Project Storm-distributes height of precipitation over a definite time interval; SCS Storm-applies to the daily precipitation depth one of project downpour distributions defined by the SCS; and HMR 52 storm-uses specified storm area and area duration precipitation curves to compute total precipitation depth.

The choice of best method depends on: modeler's objectives (determination of the project flow, hydrologic study of the watershed among others) and data availability that is the quantity (number of stations, measurement period, etc.); the quality (rain gauges, measure, etc.) of precipitation data; and the type of modeling envisaged. However, almost all methods have the specificity of homogeneous spatial and temporal rainfall depth distribution [53]. For this study, the Specified Hyetograph was adopted.

\subsubsection{Application of the HEC-HMS}

We analyzed LULC change and climate variability relationship with hydrologic processes in the UOERRB. The HEC-HMS model was selected for the study as it is: widely used to assess hydrology and water availability in agricultural catchments around the world [54] [55] [56] [57]; open source and user-friendly in relations to handling input data [58]. HEC-HMS is a semi-distributed conceptual hydrological model potentially capable of spatio-temporal simulations of rainfall-runoff relations within a basin [59] [60]. The model can be used for computation of other downstream processes for instance channel routing and reservoir routing. Globally, HEC-HMS has fruitfully been applied in catchment modeling of several river basins [51] [61] [62]. In Morocco, there are several studies on the HEC-HMS application for instance [40] [63] [64] [65] [66]. Most of the studies assessed the impact of climate and land-use on hydrology at watershed level. Reference [22] established water availability of the OER basin using different models. However, failure by most findings to account for LULCC and climatic variability effects sparked this research.

\subsubsection{LULC Change Scenarios}

We considered LULC maps of 2002 and 2016 for impact analysis. Scenario 1 is about a negative effect of deforestation and urbanization on peak flows. The CN values were estimated by increasing the surface of the urbanized/built up area, and assuming low forest density vegetation cover. For Scenario 2, we assumed that the pressure exerted on the forest cover with parallel actions to reforest the bare soils would result in clear dense forests. The percent conversion of arable land and rangeland to forest cover was assumed to be 80 and 20 respectively.

\section{Results and Discussion}

\subsection{Event-Based and Continuous-Process Calibration and Validation of the HEC-HMS Model}

The calibration was done for the event-based and the continuous-process me- 
thods and some of the results have been selectively presented. The event-based model calibration results for the 10 events between 1991-1996 and 2001-2006 are presented in Table 4. Out of the 10 events, the resultant hydrographs of six sampled events are presented in Figure 7 and Figure 8.
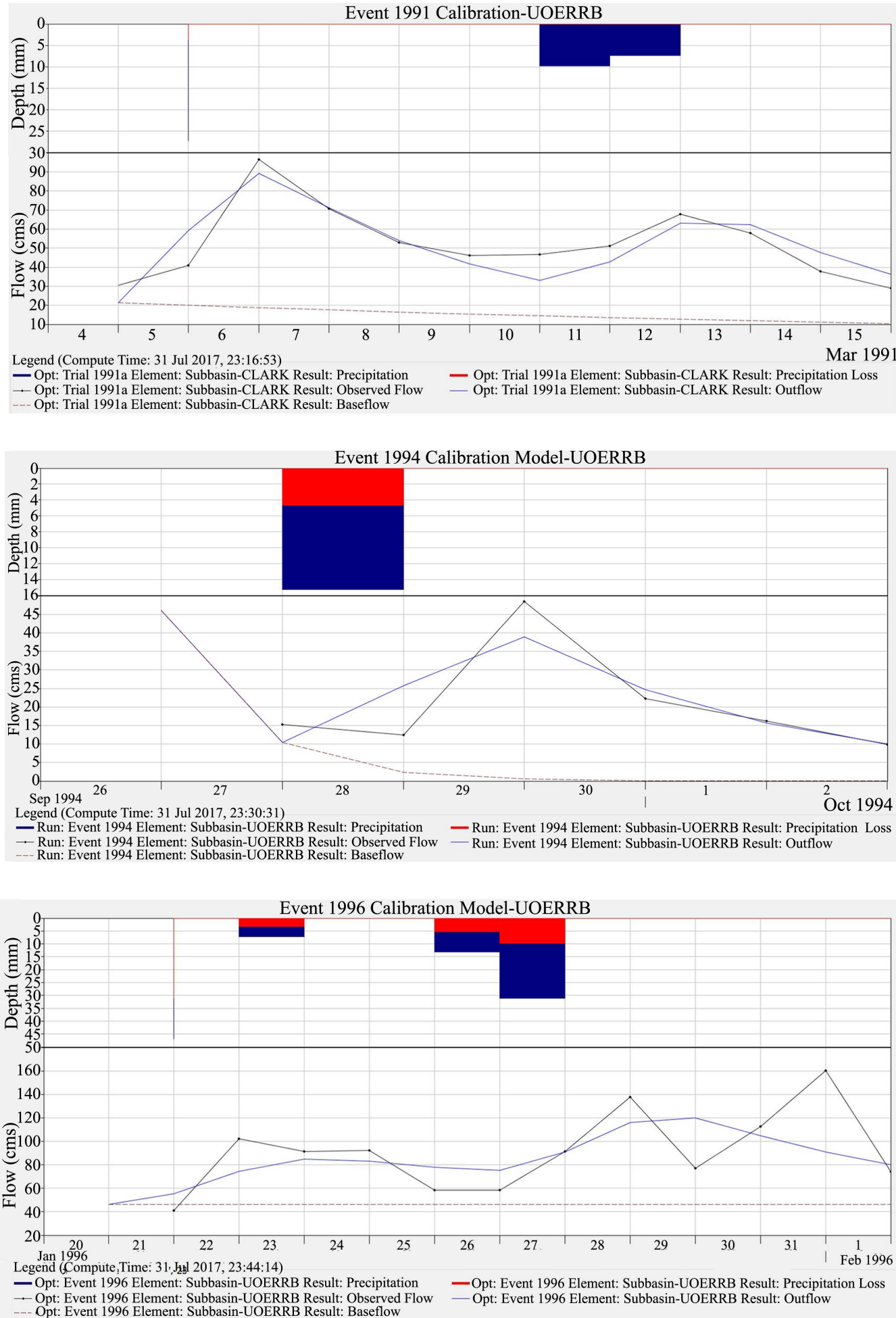

Figure 7. 1991-1996 events for model calibration. 

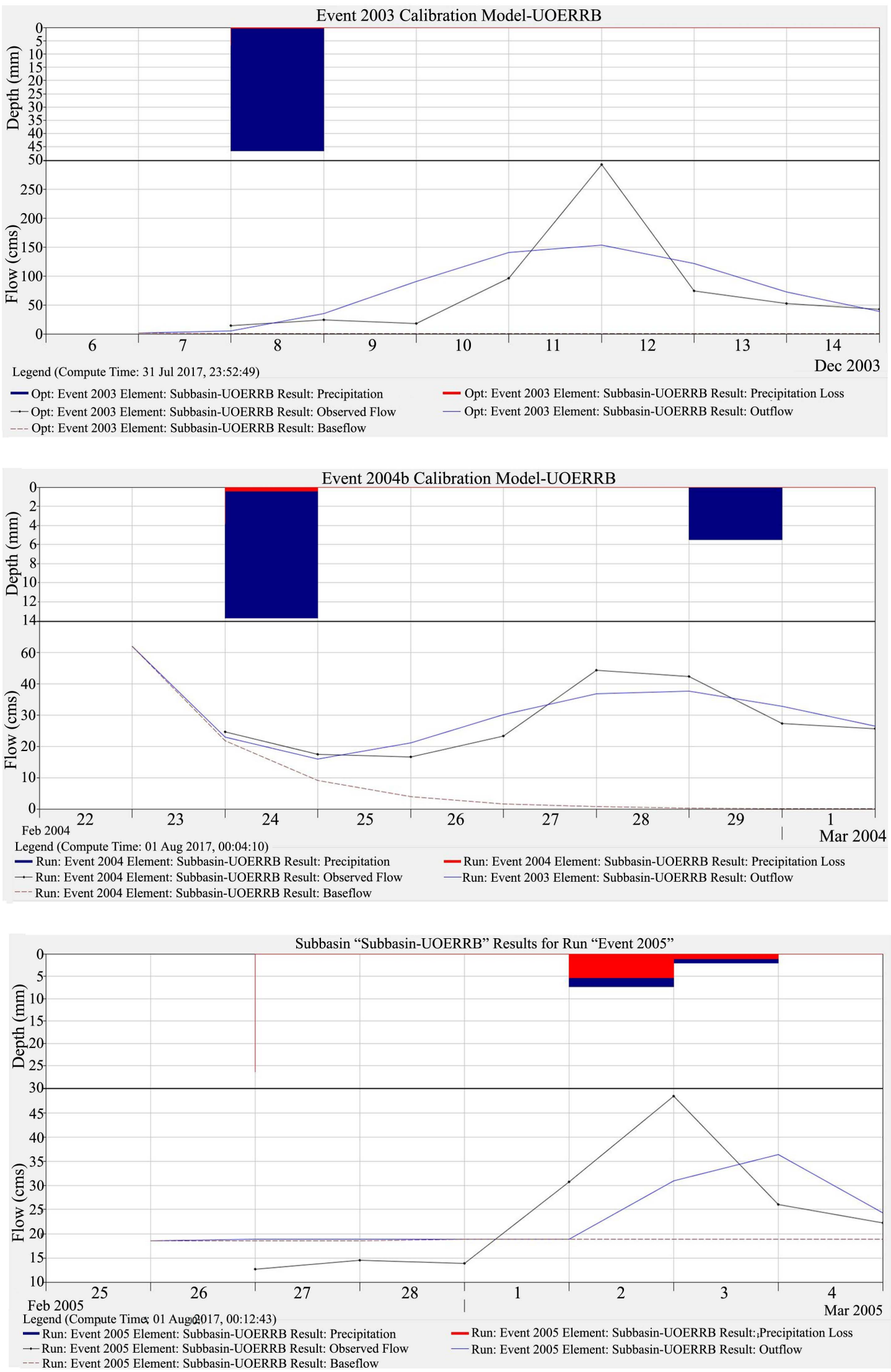

Figure 8. 2001-2006 events for model calibration. 
Table 4. HEC-HMS event-based calibration models.

\begin{tabular}{|c|c|c|c|c|c|c|c|c|c|c|c|c|}
\hline \multirow{2}{*}{ Event } & \multicolumn{2}{|c|}{ Date } & \multicolumn{2}{|c|}{ Volume (mm) } & \multicolumn{2}{|c|}{ Peak flow $\left(\mathrm{m}^{3} / \mathrm{s}\right)$} & \multicolumn{2}{|c|}{ difference } & \multicolumn{2}{|c|}{ Percent difference } & \multirow{2}{*}{$\begin{array}{l}\text { RMS } \\
\text { Error } \\
\left(\mathrm{m}^{3} / \mathrm{s}\right)\end{array}$} & \multirow{2}{*}{$\begin{array}{c}\text { Volume } \\
\text { Residual } \\
(\mathrm{mm})\end{array}$} \\
\hline & Start & End & Sim. & Obs. & Sim. & Obs. & Volume & Flow & Volume & Flow & & \\
\hline 1 & 5-Mar-1991 & 16-Mar-1991 & 49.040 & 49.3 & 87.0 & 96.6 & -0.2 & -9.6 & -0.5 & -9.9 & 8.5 & -0.23 \\
\hline 2 & 2-Apr-1992 & 10-Apr 1992 & 31.770 & 26.5 & 63.1 & 72.9 & 5.3 & -9.8 & 20.1 & -13.4 & 14.0 & -0.98 \\
\hline 3 & 29-Jul-1993 & 2-Aug-1993 & 9.500 & 7.7 & 44.1 & 38.0 & 1.8 & 6.1 & 22.9 & 16.1 & 4.1 & -0.06 \\
\hline 4 & 27-09-1994 & 3-Oct-1994 & 11.820 & 9.8 & 46.1 & 48.4 & 2.0 & -2.3 & 20.2 & -4.8 & 6.5 & 0.09 \\
\hline 5 & 28-Dec-1995 & 1-Jan-1995 & 38.750 & 25.1 & 86.6 & 123.7 & 13.6 & -37.1 & 54.2 & -30.0 & 21.8 & 0.54 \\
\hline 6 & 26-Jan-1996 & 30-Jan-1996 & 71.340 & 67.2 & 103.3 & 102.1 & 4.1 & 1.2 & 6.1 & 1.2 & 8.4 & 0.19 \\
\hline 7 & 13-Nov-2002 & 18-Nov-2002 & 3.510 & 3.2 & 8.8 & 8.6 & 0.3 & 0.2 & 10.0 & 2.3 & 0.1 & 0.00 \\
\hline 8 & 7-Dec-2003 & 15-Dec-2003 & 51.420 & 48.8 & 150.2 & 293.3 & 2.6 & -143.1 & 5.3 & -48.8 & 57.4 & 2.42 \\
\hline 9 & 23-Feb-2004 & 2-Mar-2004 & 0.760 & 0.6 & 0.8 & 1.3 & 0.2 & -0.5 & 31.0 & -38.5 & 0.2 & 0.00 \\
\hline \multirow[t]{2}{*}{10} & 26-Feb-2005 & 5-Mar-2005 & 13.630 & 13.0 & 36.8 & 48.4 & 0.7 & -11.6 & 5.2 & -24.0 & 8.9 & -0.09 \\
\hline & Average & & 28.154 & 25.1 & 62.7 & 83.3 & 3.0 & -20.7 & 17.5 & -15.0 & 13.0 & 0.19 \\
\hline
\end{tabular}

During model calibration, ranges of parameters were adopted. Table 5 summarizes the range of event-based parameters used during event-based model calibration.

Event-based validation was based on precipitation and flow data of 2006-2011 and a sample of the resultant hydrographs is presented in Figure 9. Table 6 summarizes the volume and peak flow for the 3 selected validation events. The 1991-2001 continuous-process calibration hydrograph is shown in Figure 10.

The model validation results with the 2001-2011 precipitation and stream flow data are presented in Table 7. A comparison of observed and simulated output from the SMA continuous validation modelling of daily flow series for the UOERRB is presented in Figure 10.

\subsubsection{Model Performance Evaluation}

The calibration and validation performance results of the HEC-HMS at the Tarhat gauging station, the UOERRB outlet indicate good predictability of both the event-based and continuous-process model. Table 8 summarizes the performance of the 10 calibration events considered for the study. The average NSE, $\mathrm{R}^{2}, \mathrm{RSR}$ and PBIAS were $0.697,0.474,0.828$, and -8.128 respectively.

The performance rating of the three validation events is depicted in Table 9 with average NSE, $\mathrm{R}^{2}$, RSR and PBIAS values of $0.581,0.692,0.596$, and 3.213 respectively.

For the continuous-process, the NSE, $\mathrm{R}^{2}$, RSR and PBIAS for bothcalibration and validation models are presented in Table 10 .

\subsubsection{Simulation of Future Land-Use and Land Cover Scenarios}

A simple future LULC distribution pattern in Scenario 1, used as a direct input to the calibrated event No. 6 generated various CNs that resulted in numerous volumes and peak flows (Table 11). Similarly, Scenario 2 simulation (increase in forest cover) resulted in volume and peak flow values presented in Table 12. 
Table 5. Range of calibration parameter values, 1991-1996 and 2001-2006.

\begin{tabular}{cccc}
\hline Parameter & Units & Range & Average \\
\hline Clark Unit Hydrograph - Storage Coefficient & Hr. & $4.0-82.0$ & 42.0 \\
Clark Unit Hydrograph - Time of Concentration & $\mathrm{Hr}$. & $13.3-138.0$ & 131.5 \\
Recession - Initial Discharge & $\mathrm{m}^{3} / \mathrm{s}$ & $4.0-52.0$ & 10.9 \\
Recession - Recession Constant & & $0.2-1.0$ & 0.9 \\
Recession - Threshold Discharge & $\mathrm{m}^{3} / \mathrm{s}$ & $0.4-39.5$ & 0.1 \\
SCS Curve Number - Curve Number & & $36.0-99.0$ & 48.5 \\
$\begin{array}{c}\text { SCS Curve Number - Initial Abstraction } \\
\text { Mm }\end{array}$ & $0.00-2.25$ & 1.0
\end{tabular}
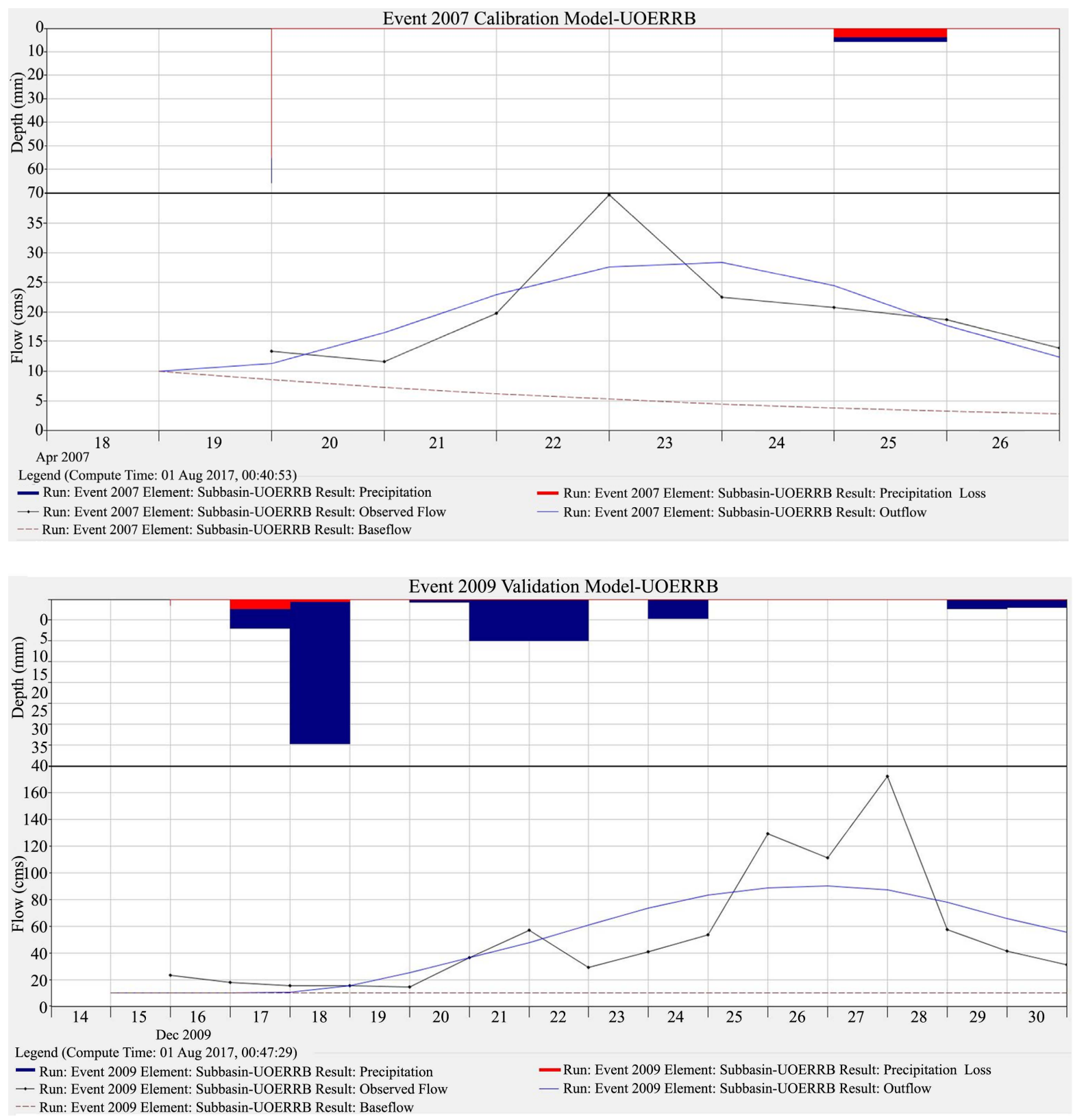

Figure 9. 2006-2011: Events for model validation. 
Table 6. Validation model event results for Tarhat, 2006-2011.

\begin{tabular}{|c|c|c|c|c|c|c|c|c|c|c|c|c|}
\hline \multirow{2}{*}{ Event } & \multicolumn{2}{|c|}{ Date } & \multicolumn{2}{|c|}{ Volume (mm) } & \multicolumn{2}{|c|}{ Peak flow $\left(\mathrm{m}^{3} / \mathrm{s}\right)$} & \multicolumn{2}{|c|}{ Difference } & \multicolumn{2}{|c|}{ Percent difference } & \multirow{2}{*}{$\begin{array}{l}\text { RMS Error } \\
\qquad\left(\mathrm{m}^{3} / \mathrm{s}\right)\end{array}$} & \multirow{2}{*}{$\begin{array}{c}\text { Volume } \\
\text { Residual (mm) }\end{array}$} \\
\hline & Start & End & Sim. & Obs. & Sim. & Obs. & Vol. & Qmax & Volume & Flow & & \\
\hline 1 & 23-Jan-06 & 31-Jan-06 & 13.7 & 12.8 & 37.7 & 40.4 & 0.8 & -2.7 & 6.5 & -6.7 & 6.7 & -0.5 \\
\hline 2 & 19-Apr-07 & 27-Apr-07 & 13.2 & 12.6 & 28.4 & 39.7 & 0.6 & -11.3 & 4.5 & -28.5 & 5.1 & 0.2 \\
\hline 3 & 15-Dec-09 & 31-Dec-09 & 67.7 & 68.5 & 90.5 & 172.6 & -0.8 & -82.1 & -1.1 & -47.6 & 29.1 & -1.2 \\
\hline Avg. & & & 31.5 & 31.3 & 52.2 & 84.2 & 0.2 & -32 & 3.3 & -27.6 & 13.6 & -0.5 \\
\hline
\end{tabular}

Table 7. Continuous-process calibration and validation.

\begin{tabular}{|c|c|c|c|c|c|c|c|c|c|c|c|c|}
\hline \multirow{2}{*}{ Continuous-process } & \multicolumn{2}{|c|}{ Date } & \multicolumn{2}{|c|}{ Volume (mm) } & \multicolumn{2}{|c|}{ Peak flow $\left(\mathrm{m}^{3} / \mathrm{s}\right)$} & \multicolumn{2}{|c|}{ Difference } & \multicolumn{2}{|c|}{ Percent difference } & \multirow{2}{*}{$\begin{array}{l}\text { RMS Error } \\
\qquad\left(\mathrm{m}^{3} / \mathrm{s}\right)\end{array}$} & \multirow{2}{*}{$\begin{array}{c}\text { Volume } \\
\text { Residual (mm) }\end{array}$} \\
\hline & Start & End & Sim. & Obs. & Sim. & Obs. & Volume & Qmax & Volume & Flow & & \\
\hline Calibration & 1-Sep-91 & 31-Aug-01 & 3672.5 & 4421.3 & 130.8 & 160.4 & -748.8 & -29.6 & -16.9 & -18.5 & 8.0 & -748.8 \\
\hline Validation & $1-$ Sep-01 & 31-Aug-11 & 4094.2 & 4775.4 & 75.8 & 293.3 & -681.2 & -217.5 & -14.3 & -74.2 & 13.4 & -700.7 \\
\hline
\end{tabular}

Table 8. Event-based calibration performance rating.

\begin{tabular}{|c|c|c|c|c|c|c|}
\hline Event & Start date & End date & NSE & $\mathrm{R}^{2}$ & RSR & PBIAS \\
\hline 1 & 5-Mar-91 & 16-Mar-91 & 0.783 & 0.784 & 0.465 & 0.414 \\
\hline 2 & 2-Apr-92 & 10-Apr-92 & 0.525 & 0.394 & 0.790 & -9.963 \\
\hline 3 & 29-Jul-93 & 2-Aug-93 & 0.826 & 0.014 & 1.177 & -37.114 \\
\hline 4 & 27-09-1994 & 3-Oct-94 & 0.718 & 0.155 & 1.099 & -28.455 \\
\hline 5 & 28-Dec-95 & 1-Jan-95 & 0.561 & 0.606 & 0.400 & 0.285 \\
\hline 6 & 26-Jan-96 & 30-Jan-96 & 0.895 & 0.708 & 0.648 & 7.297 \\
\hline 7 & 13-Nov-02 & 18-Nov-02 & 0.996 & 0.899 & 1.173 & 0.781 \\
\hline 8 & 7-Dec-03 & 15-Dec-03 & 0.506 & 0.517 & 0.700 & -0.701 \\
\hline 9 & 23-Feb-04 & 2-Mar-04 & 0.775 & 0.282 & 1.034 & -11.003 \\
\hline 10 & 26-Feb-05 & 5-Mar-05 & 0.381 & 0.384 & 0.789 & -2.824 \\
\hline Average & & & 0.697 & 0.474 & 0.828 & -8.128 \\
\hline
\end{tabular}

Table 9. Event-based Validation performance rating.

\begin{tabular}{|c|c|c|c|c|c|c|}
\hline Event & Start date & End date & NSE & $\mathrm{R}^{2}$ & RSR & PBIAS \\
\hline 1 & 23-Jan-06 & 31-Jan-06 & 0.600 & 0.906 & 0.497 & 7.598 \\
\hline 2 & 19-Apr-07 & 27-Apr-07 & 0.598 & 0.608 & 0.628 & 0.349 \\
\hline 3 & 15-Dec-09 & 31-Dec-09 & 0.546 & 0.563 & 0.663 & 1.691 \\
\hline Average & & & 0.581 & 0.692 & 0.596 & 3.213 \\
\hline
\end{tabular}

Table 10. Continuous-process model performance for Tarhat station.

\begin{tabular}{ccccccc}
\hline Continuous-process & Start date & End date & NSE & R2 & RSR & PBIAS \\
\hline Calibration & 1 -Sep-91 & 31-Aug-01 & 0.598 & 0.637 & 0.622 & 16.946 \\
Validation & 1 -Sep-01 & 31-Aug-11 & 0.341 & 0.361 & 0.800 & 14.683 \\
\hline
\end{tabular}


Table 11. Predicted CN, max flow and discharge volume for Scenario 1.

\begin{tabular}{cccccc}
\hline \multirow{2}{*}{$\begin{array}{c}\text { Percent forest } \\
\text { reduction }\end{array}$} & CN & \multicolumn{2}{c}{ Peak flow $\left(\mathrm{m}^{3} / \mathrm{s}\right)$} & \multicolumn{2}{c}{ Runoff Volume $(\mathrm{mm})$} \\
\cline { 3 - 6 } & & Simulated & Observed & simulated & observed \\
\hline 10 & 71 & 80.4 & 137.7 & 20.09 & 29.24 \\
20 & 72 & 81.3 & 137.7 & 20.22 & 29.24 \\
50 & 74.9 & 84.3 & 137.7 & 20.64 & 29.24 \\
\hline
\end{tabular}

Table 12. Predicted CN, max flow and discharge volume for Scenario 2.

\begin{tabular}{cccccc}
\hline \multirow{2}{*}{$\begin{array}{c}\text { Percent forest } \\
\text { increase }\end{array}$} & CN & \multicolumn{2}{c}{ Peak flow $\left(\mathrm{m}^{3} / \mathrm{s}\right)$} & \multicolumn{2}{c}{ Runoff Volume $(\mathrm{mm})$} \\
\cline { 3 - 5 } & & Simulated & Observed & Simulated & Observed \\
\hline 10 & 69.3 & 78.8 & 137.7 & 19.87 & 29.24 \\
20 & 68.5 & 78.2 & 137.7 & 19.78 & 29.24 \\
50 & 66.3 & 76.4 & 137.7 & 19.53 & 29.24 \\
\hline
\end{tabular}
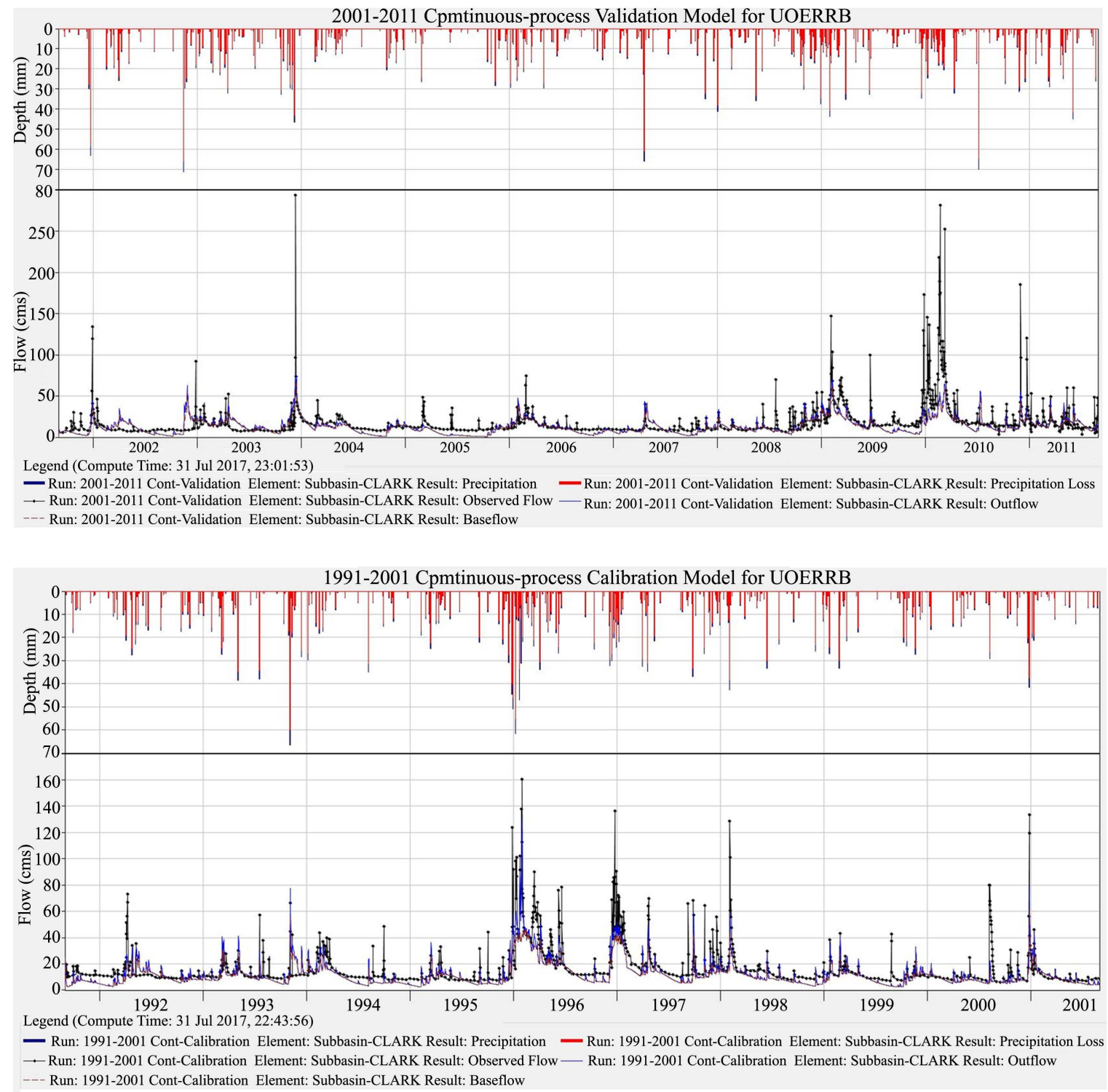

Figure 10. Continuous-process calibration (1991-2001) and validation (2001-2011). 


\subsubsection{Typical Peak Streamflow Trends and Duration}

Vegetation plays an attenuating and important role during flood periods. An increase in vegetation results in a corresponding delay in the surface runoff thus the flood point is attenuated. From Table 13 and Figure 11, a decrease in vegetation cover reflected in $\mathrm{CN}$ increase directly resulted in peak flow increase.

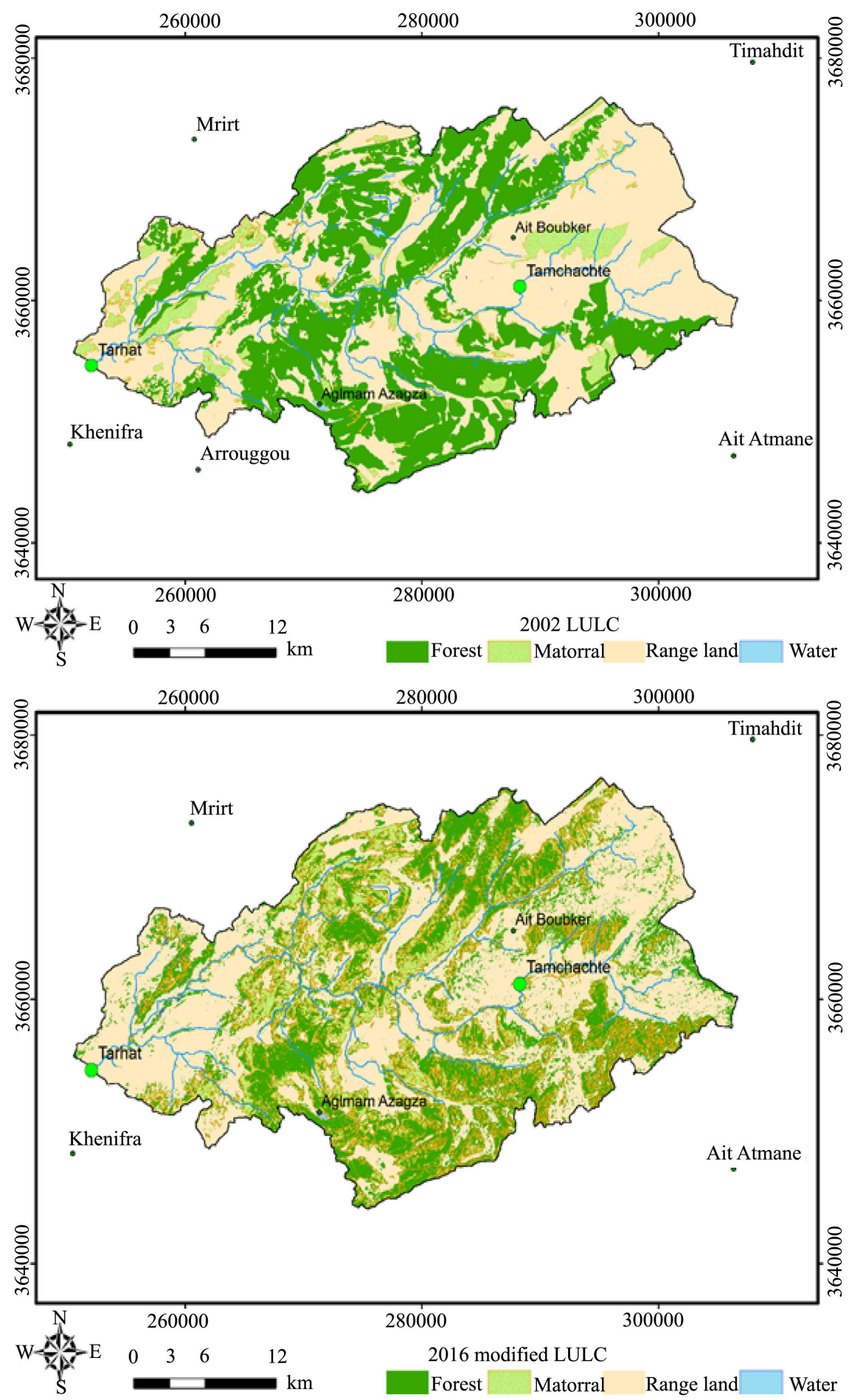

Figure 11. 2002 and 2016 LULC comparison maps for UOERRB. 
Table 13. 2002 and 2016 land use volume and peak flows comparison.

\begin{tabular}{cccccc}
\hline \multirow{2}{*}{ Land use } & CN & \multicolumn{2}{c}{ Peak flow $\left(\mathrm{m}^{3} / \mathrm{s}\right)$} & \multicolumn{2}{c}{ Run off Volume $(\mathrm{mm})$} \\
\cline { 3 - 6 } & & Simulated & Observed & simulated & Observed \\
\hline 2002 & 67.8 & 77.6 & 137.7 & 19.7 & 29.24 \\
2016 (Digitized) & 70 & 79.5 & 137.7 & 19.96 & 29.24 \\
2016 (Modified) & 68.8 & 78.4 & 137.7 & 19.81 & 29.24 \\
\hline
\end{tabular}

Climate variability was assessed as the difference between the flow rates of 1980 and 2011. The stream flow rates increased by $1261 \mathrm{Mm}^{3}$ within this period. The total flow difference between 1981 and 2011 hydrologic years was $202 \mathrm{Mm}^{3}$. Temporally, although climate variability has accelerated an increase in the basin flows, there was a clearly observed decreasing trend of flows in 2001. The decrease was a result of a lower rainfall in the basin. From 1975-2011, the average water flow was approximately $684 \mathrm{Mm}^{3} /$ year with a maximum of $5692 \mathrm{Mm}^{3} /$ year and a minimum of $265 \mathrm{Mm}^{3} /$ year.

\subsection{Discussion}

The basin characteristics such as the elongated shape delays the flow of water to the outlet during a flood period and thus justify the results of the HEC-HMS model. We observed strong annual streamflow variation and the average inter-annual monthly flow was $21 \mathrm{~m}^{3} / \mathrm{s}$. Variation in basin precipitation was found influential to streamflow trends thus the positive correlation between precipitation and peak flows. The changes in precipitation are directly reflected in surface runoff pattern (magnitude and frequency) of peak flows for the study period.

\subsubsection{Land-Use and Land Cover Change Impact Analysis}

We focused on determining the major LULCC based on the 2002 and 2016 LULC maps. The forest cover increased by 22.4 percent between 2002 and 2016 indicating a remarkable increase in the basin's vegetation cover. This increase can be explained by the significant annual average rainfall increase from 690 to $714.1 \mathrm{~mm}$ over the period 2002-2016. Besides, the increased basin's re/afforestation rate in the recent decades has also arguably offset land degradation. On a contrary, there is a remarkable decrease in area covered by matorral between the two years. However, this study is strictly limited to changes in LULC pattern (Figure 11) rather than LULC analyses. From the results of Scenario 2, considering a proposed 50 percent increase in forest cover, the simulated peak flow decreased by 9 percent. From the results of the two scenarios of vegetation cover trends, there is positive and negative $\mathrm{CN}$ effect and thus hydrologic response of the basin. Considering the proposed LULC change Scenario 1, the increase in simulated peak flows reflects high vegetation cover degradation. The results are sensitive to the $\mathrm{CN}$ parameter with the same rainfall data. However, flooding is not very sensitive to the variation of this parameter. $\mathrm{CN}$ value analysis is physi- 
cally expressed by the modification of dense vegetation into less dense (thin) vegetation. This partly explains the increased surface runoff generation from continued felling of trees in the basin.

From the LULC maps, forest cover accounts for 32.6 percent of total watershed area in 2002 compared to the 39.9 percent in 2016. The expansion rate of forest land attributed to reforestation directly affects the magnitudes of runoff volume and peak flows as presented in scenarios. The information on LULC change serves as a vital tool in decisions making and policy formulation by the local authority (ABHOER). From the 2016 LULC map, we categorize the UOERRB as an agricultural basin and propose irrigated land expansion to be sustainably balanced with re/afforestation to offset the likely tremendous impact on the basin's available water resources.

Considering the 10 calibration events, the performance evaluation ratings were generally good. However, events 3 and 4 produced relatively poor results. This is reflected in better average validation performance rating values compared to the calibrated ones. Out of the 10 calibration events, only one had an NSE value less than 0.5 indicating a very good performance accordingly. The calibration results indicate an adequately done process where average and maximum NSE values are 0.697 and 0.996 respectively. In general, most of the RSR and PBIAS values are considered good according to performance ratings. Despite achieving relatively less acceptable RSR values, the overall performance is considered satisfactory. Generally considering average performance values, the calibration model was accurate.

The ratings indicate a strong correlation between simulated and observed runoff volumes and peak discharges for all chosen events. From the event-based validated model (2006-2011), the simulated daily hydrograph matched with observed stream flow with an underestimation of peak flows. The event-based validation performance results obtained were satisfactory and acceptable to simulate the basin runoff for future LULC pattern projection.

\subsubsection{Continuous-Process Simulation Analysis and Scenario}

The 1991-2001 continuous process calibration model comparisons between the observed and simulated flow rates hydrographs at the Tarhat station are presented in Figure 10. The calibration results indicate a good generated hydrograph thus an adequately done process. The performance rating values indicate a strong relationship between observed and simulated values achieved during calibration. However, there was a multitude of spikes during the calibration period. The simulated model timing of the peak matches well, but the peak flow is underestimated by $18.5 \%$. Besides, there is under prediction of low flows for the simulated model. Considering the continuous-process simulation, the model fairly reproduced the observed hydrographs for 1991-2001. However, there are some scatters in peak flows. One can conclude that the calibrated HEC-HMS model simulates the runoff and it can be used to evaluate the effects of LULC change on runoff generation in the UOERRB. 
Similarly, comparison of the simulated and observed runoff hydrographs with the continuous-process method based on the same performance criteria, indicate good model results. Relative to calibration, the event-based model validation performance during validation is generally reduced. However, the results remain adequately acceptable with average NSE, $\mathrm{R}^{2}$, RSR and PBIAS values of 0.581 , $0.692,0.596$, and 3.213 respectively. For 2001-2011 continuous-process validation, the simulated flow values fairly correlate with the observed values. However, out of the 4-performance rating, the model satisfactorily fulfilled only the RSR and PBIAS. Besides, the NSE and $\mathrm{R}^{2}$ of 0.341 and 0.361 respectively are close to 0.400 considered satisfactory. Therefore, the prediction of the validation model can be considered acceptable.

\subsubsection{Sensitivity Analysis of SCS-CN and SMA Parameters}

From the model results, imperviousness; simple canopy-max storage; SMA's soil storage, tension storage, and maximum infiltration were the most sensitive parameters for estimating runoff by continuous-process simulation. During the non-winter months, the basin follows a wetting and drying sequence. However, this study assumed only dry periods during SMA continuous-process modelling. The calibrated GW-1 storage depth varied between 1.45 and $4.5 \mathrm{~mm}$, while the GW-2 storage depth values ranged between 22.5 to $36 \mathrm{~mm}$. The GW-1 storage coefficient varied between 18 and 85 hours. The GW-2 storage coefficient values ranged from 36 to 1485 hours. This variability clearly indicates a non-uniformity behavior between the interflow and groundwater flow throughout the water years [67]. Overall, the model is reliable to reproduce stream flows in the basin and the abnormalities in the results can be explained by the impact of precipitation uncertainties.

Considering the UOERRB, the measured precipitation of Tarhat and Tamchachte stations are considered non-representative due to high spatial variability in the basin rainfall. The HEC-HMS results obtained are similar to those of [40] [64] [65] [68] [68]. The mean NSE values for calibration and validation were 0.65 and 0.62 [64] and 0.74 and 0.73 [40]. The average NSE values were 0.99 for studies by [65] [69]. However, all these studies were carried out from other basins rather than UOERRB and most of the research studies were event-based.

In SCS-CN event-based model, initial soil moisture is normally classified into dry, moderate and wet conditions that may lead to increased simulation error. However, the initial soil moisture content was not measured in field. The study was based on AMC-II conditions and [70] notes difficult in correct selection of $\mathrm{CN}$ values from available handbook tables. Development of SMA continuous-process model requires several parameters for quality model outputs. However, most of these parameters were not readily available and were thus deduced from published research. The Lands at images used in this study were taken during different weather seasons and thus separate analysis of these images could yield precise representative LULC and better SMA validation model results. 


\section{Conclusion}

In this study, the HEC-HMS modelling approach is used to explore the event-based (SCS-CN) and the continuous-process (SMA) simulation of land-use and land cover change (LULCC) impact on water balance. The HEC-HMS performance results were good with average calibration NSE values of 0.740 and 0.585 for event-based and continuous-process respectively. We argue that the basin's hydrologic response to positive and negative LULCC scenarios is significant. The HEC-HMS model simulation of the daily stream flow at basin outlet was considered satisfactorily good and acceptable. However, there is a slight under and over prediction of the high flows. Like with hydrologic research, the results of the study should be carefully interpreted with some measure of uncertainty. The results of the model indicated that an increase in forest cover and irrigated agricultural land expansion negatively impacted the peak flow and river stream discharge volumes. This hydrological modeling could also be used to facilitate subsequent hydrological studies within the region. The outcomes of this study can be vital in the future flood prediction and warning. For further development of this study, we recommend: detailed LULC survey within the basin to verify the HEC-HMS; adopting field-based data approaches to establish the SMA parameters; localized PET measurements to give more representative results; and evaluating significance of snow effect on stream flows.

\section{Acknowledgements}

Professor El Garouani Abdelkader for his full devotion and invaluable and precise criticisms towards the study. The Laboratory of Geo-Resources and Environment of the Faculty of Sciences and Techniques of Fez, the Director. Agence du Bassin Hydraulique de l'Oum ErRabia, which was the source of flow and precipitation data.

\section{Conflicts of Interest}

The authors declare no conflicts of interest regarding the publication of this paper.

\section{References}

[1] Cheddadi, R., et al. (2015) A History of Human Impact on Moroccan Mountain Landscapes. African Archaeological Review, 32, 233-248. https://doi.org/10.1007/s10437-015-9186-7

[2] Tekken, V. and Kropp, J.P. (2012) Climate-Driven or Human-Induced: Indicating Severe Water Scarcity in the Moulouya River Basin (Morocco). Water, 4, 959-982. https://doi.org/10.3390/w4040959

[3] Anaba, L.A., Banadda, N., Kiggundu, N., Wanyama, J., Engel, B. and Moriasi, D. (2017) Application of Swat to Assess the Effects of Land Use Change in the Murchison Bay Catchment in Uganda. Computational Water, Energy, and Environmental Engineering, 6, 24-40. https://doi.org/10.4236/cweee.2017.61003

[4] Baker, T.J. and Miller, S.N. (2013) Using the Soil and Water Assessment Tool 
(Swat) to Assess Land Use Impact on Water Resources in an East African Watershed. Journal of Hydrology, 486, 100-111.

https://doi.org/10.1016/j.jhydrol.2013.01.041

[5] Guo, H., Hu, Q. and Jiang, T. (2008) Annual and Seasonal Streamflow Responses to Climate and Land-Cover Changes in the Poyang Lake Basin, China. Journal of Hydrology, 355, 106-122. https://doi.org/10.1016/j.jhydrol.2008.03.020

[6] Hamel, P., Chaplin-Kramer, R., Sim, S. and Mueller, C. (2015) Science of the Total Environment a New Approach to Modeling the Sediment Retention Service (Invest 3. 0): Case Study of the Cape Fear Catchment, North Carolina, USA. Science of the Total Environment, 524-525, 166-177. https://doi.org/10.1016/j.scitotenv.2015.04.027

[7] Li, Z., Liu, W.Z., Zhang, X.C. and Zheng, F.L. (2009) Impacts of Land Use Change and Climate Variability on Hydrology in an Agricultural Catchment on the Loess Plateau of China. Journal of Hydrology, 377, 35-42.

https://doi.org/10.1016/j.jhydrol.2009.08.007

[8] Meng, F.H., Liu, T., Huang, Y., Luo, M., Bao, A. and Hou, D.W. (2016) Quantitative Detection and Attribution of Runoff Variations in the Aksu River Basin. Water, 8 , 338. https://doi.org/10.3390/w8080338

[9] Milewski, A., Seyoum, W.M., Elkadiri, R. and Durham, M. (2020) Multi-Scale Hydrologic Sensitivity to Climatic and Anthropogenic Changes in Northern Morocco. Geosciences, 10, 13. https://doi.org/10.3390/geosciences10010013

[10] Dabour, N. (2006) Water Resources and Their Use in Agriculture in Arab Countries. Journal of Economic Cooperation among Islamic Countries, 27, 1-38.

[11] Jaw, T., Li, J.L., Hsu, K.L., Sorooshian, S. and Driouech, F. (2015) Evaluation for Moroccan Dynamically Downscaled Precipitation from GCM CHAM5 and Its Regional Hydrologic Response. Journal of Hydrology. Regional Studies, 3, 359-378. https://doi.org/10.1016/j.ejrh.2015.02.008

[12] Diao, X.S., Dinar, A., Roe, T. and Tsur, Y. (2008) A General Equilibrium Analysis of Conjunctive Ground and Surface Water Use with an Application to Morocco. Agricultural Economics, 38, 117-135. https://doi.org/10.1111/j.1574-0862.2008.00287.x

[13] Diyer, M., Namrani, H. and Elkadiri, A. (2013) Land Use and Land Management Practices in Environmental Perspective.

[14] Linstädter, A., et al. (2010) Land Use and Land Cover in Southern Morocco: Managing Unpredictable Resources and Extreme Events. Impacts of Global Change on the Hydrological Cycle in West and Northwest Africa, 612-633.

[15] Bouslihim, Y., et al. (2016) Hydrologic Modeling Using SWAT and GIS, Application to Subwatershed Bab-Merzouka (Sebou, Morocco). Journal of Geographical Systems, 8, 20-27. https://doi.org/10.4236/jgis.2016.81002

[16] Marchane, A., Tramblay, Y., Hanich, L., Ruelland, D. and Jarlan, L. (2017) Climate Change Impacts on Surface Water Resources in the Rheraya Catchment (High Atlas, Morocco). Hydrological Sciences Journal, 62, 979-995. https://doi.org/10.1080/02626667.2017.1283042

[17] Barakat, A., El Rais, M., Rais, J., Aghezzaf, B. and Slassi, M. (2016) International Soil and Water Conservation Research Assessment of Spatial and Seasonal Water Quality Variation of Oum Er Rbia River (Morocco) Using Multivariate Statistical Techniques. International Soil and Water Conservation Research, 4, 284-292. https://doi.org/10.1016/j.iswcr.2016.11.002

[18] El Jazouli, A., Barakat, A., Khellouk, R., Rais, J. and El Baghdadi, M. (2018) Remote 
Sensing and GIS Techniques for Prediction of Land Use Land Cover Change Effects on Soil Erosion in the High Basin of the Oum Er Rbia River (Morocco). Remote Sensing Applications. Society and Environment, No. 13, 361-374.

[19] Yan, T.Z., Shen, Z.Y. and Bai, J.W. (2017) Spatial and Temporal Changes in Temperature, Precipitation, and Streamflow in the Miyun Reservoir Basin of China. Water, 9, 78. https://doi.org/10.3390/w9020078

[20] El Azhari, M. and Loudyi, D. (2019) Analysis of the Water-Energy Nexus in Central Oum Er-Rbia Sub-Basin-Morocco. International Journal of River Basin Management, 17, 13-24. https://doi.org/10.1080/15715124.2018.1446966

[21] World Bank (2017) Managing Urban Water Scarcity in Morocco. World Bank, Washington DC.

[22] Chaponniere, A. and Smakhtin, V. (2006) A Review of Climate Change Scenarios and Preliminary Rainfall Trend Analysis in the Oum Er Rbia Basin, Morocco. International Water Management Institute, Colombo, 1-16.

[23] Tangermann, J. and Bennani, H.A. (2014) Assessing the Evidence: Migration, Environment and Climate Change in Morocco. IOM, Le Grand-Saconnex.

[24] Haan, C.T., Johnson, H.P., Brakensiek, D.L. and American Society of Agricultural Engineers (1982) Hydrologic Modeling of Small Watersheds.

https://wur.on.worldcat.org/oclc/8775569

[25] Vieux, B.E. (2016) Distributed Hydrologic Modeling Using GIS. Springer, Dordrecht. https://wur.on.worldcat.org/oclc/957276992

[26] Singh, V.P. (2018) Hydrologic Modeling: Progress and Future Directions. Geoscience Letters, 5, Article No. 15. https://doi.org/10.1186/s40562-018-0113-Z

[27] Serban, P. (1990) World Meteorological Organization Operational Hydrology Report No. 34 Hydrological Models for Water-Resources System Design and Operation.

[28] Dutta, P. and Sarma, A.K. (2020) Hydrological Modeling as a Tool for Water Resources Management of the Data-Scarce Brahmaputra Basin. Journal of Water and Climate Change, jwc2020186. https://doi.org/10.2166/wcc.2020.186

[29] Ougougdal, H.A., Khebiza, M.Y., Messouli, M. and Lachir, A. (2020) Assessment of Futurewater Demand and Supply under Ipcc Climate Change and Socio-Economic Scenarios, Using a Combination of Models in Ourika Watershed, High Atlas, Morocco. Water, 12, 1751. https://doi.org/10.3390/w12061751

[30] Ben Salem, A., Messouli, M. and Yacoubi-Khebiza, M. (2011) Developing an Oasis-Based Water Management Tool: Ecohydrologic Approach and Weap Software for a Large Arid Catchment in Morocco. International Journal of Water Resources and Arid Environments, 1, 387-396.

[31] Johannsen, I.M., Hengst, J.C., Goll, A., Höllermann, B. and Diekkrüger, B. (2016) Future of Water Supply and Demand in the Middle Drâa Valley, Morocco, under Climate and Land Use Change. Water, 8, 11-13. https://doi.org/10.3390/w8080313

[32] Choukri, F., et al. (2020) Distinct and Combined Impacts of Climate and Land Use Scenarios on Water Availability and Sediment Loads for a Water Supply Reservoir in Northern Morocco. International Soil and Water Conservation Research, 8, 141-153. https://doi.org/10.1016/j.iswcr.2020.03.003

[33] Sertel, E., Imamoglu, M.Z., Cuceloglu, G. and Erturk, A. (2019) Impacts of Land Cover/Use Changes on Hydrological Processes in a Rapidly Urbanizing Mid-Latitude Water Supply Catchment. Water, 11, 1075. https://doi.org/10.3390/w11051075 
[34] Plesca, I., et al. (2012) Model Intercomparison to Explore Catchment Functioning: Results from a Remote Montane Tropical Rainforest. Ecological Modelling, 239, 3-13. https://doi.org/10.1016/j.ecolmodel.2011.05.005

[35] Khaddor, I., Achab, M. and Alaoui, A.H. (2015) Simulation of Rainfall-Runoff Using GIS, Hydrologic Modeling System and SCS Curves Number: Application to the Meghougha Watershed (Tangier, NW Morocco). European Journal of Scientific Research, 130, 31-45.

[36] El Khalki, E.M., et al. (2018) Comparison of Modeling Approaches for Flood Forecasting in the High Atlas Mountains of Morocco. Arabian Journal of Geosciences, 11, Article No. 415. https://doi.org/10.1007/s12517-018-3752-7

[37] Aqnouy, M., El Massari, J.E.S., Bouadila, A., Bouizrou, I. and Aoulad Mansour, M.R. (2018) Application of Hydrological Model "HEC HMS" in A Mediterranean Watershed (Ouedlaou, Northern of Morocco). International Journal of Innovation and Applied Studies, 24, 1773-1781.

[38] El Khalki, E.M., et al. (2020) Validation of the AROME, ALADIN and WRF Meteorological Models for Flood Forecasting in Morocco. Water, 12, 437. https://doi.org/10.3390/w12020437

[39] Benkirane, M., et al. (2020) an Approach for Flood Assessment by Numerical Modeling of Extreme Hydrological Events in the Zat Watershed (High Atlas, Morocco). Urban Water Journal, 17, 381-389. https://doi.org/10.1080/1573062X.2020.1734946

[40] Khattatı, M., et al. (2016) Hydrological Modeling of Aguibatezziar Watershed (Morocco), Comparative Study of Two Different Hydrological Models. Journal of Geographical Systems, 8, 50-56. https://doi.org/10.4236/jgis.2016.81005

[41] Rochdane, S., Reichert, B., Messouli, M., Babqiqi, A. and Khebiza, M.Y. (2012) Climate Change Impacts on Water Supply and Demand in Rheraya Watershed (Morocco), with Potential Adaptation Strategies. Water, 4, 28-44. https://doi.org/10.3390/w4010028

[42] Acil, N. (2016) Remote Sensing-Based Monitoring of Snow Cover Dynamics and Its Influence on Vegetation Growth in the Middle Atlas Mountains. Lund University, Lund.

[43] Balaghi, A.R., Hairech, T.E.L., Alaouri, M. and Motaouakil, S. (2016) Climate Change Impact Assessment Using MOSAICC in Morocco. Fao, Rome.

[44] Bouabdelli, M. (1994) Tectonique de l'Est du Massif hercynien central (zone d'Azrou-Khénifra). Bulletin de Institut Scientifique, Rabat, No. 18, 145-168.

[45] Bouabdelli, M. and Piqué, A. (1996) Du bassinsurdécrochement au bassind'avant-pays: Dynamique du bassind'Azrou-Khénifra (Marochercynien central). Journal of African Earth Sciences, 23, 213-224. https://doi.org/10.1016/S0899-5362(96)00063-2

[46] Pande, C.B., Moharir, K.N., Khadri, S.F.R. and Patil, S. (2018) Study of Land Use Classification in an Arid Region Using Multispectral Satellite Images. Applied Water Science, 8, Article No. 123. https://doi.org/10.1007/s13201-018-0764-0

[47] Msaddek, M. (2016) Effetd'occupation du sol sur la réponsehydrologique du Haut bassinOumErRabia. Master's Thesis, Université Sidi Mohammed Ben Abdellah, Fez.

[48] El Garouani, A., Mulla, D.J., El Garouani, S. and Knight, J. (2017) Analysis of Urban Growth and Sprawl from Remote Sensing Data: Case of Fez, Morocco. International Journal of Sustainable Built Environment, 6, 160-169. https://doi.org/10.1016/j.ijsbe.2017.02.003

[49] Feldman, A.D. (2000) Hydrologic Modeling System HEC-HMS, Technical Reference Manual. Technical Reference Manual, 45. 
[50] Scharffenberg, W.A. (2013) Hydrologic Modeling System HEC-HMS, User'a Manual, 442 .

[51] Song, X., Kong, F. and Zhu, Z. (2011) Application of Muskingum Routing Method with Variable Parameters in Ungauged Basin. Water Science and Engineering, 4, 1-12.

[52] Dhami, B.S. and Pandey, A. (2013) Comparative Review of Recently Developed Hydrologic Models. Journal of Indian Water Resources Society, 33, 34-42.

[53] US Army Corps of Engineers (2017) Hydrologic Modeling System; Application Guide. US Army Corps of Engineers, Washington DC, 158.

[54] Konecná, J., et al. (2020) Using WaTEM/SEDEM and HEC-HMS Models for the Simulation of Episodic Hydrological and Erosion Events in A Small Agricultural Catchment. Soil and Water Research, 15, 18-29. https://doi.org/10.17221/202/2018-SWR

[55] Al-Mukhtar, M. and Al-Yaseen, F. (2019) Modeling Water Quality Parameters Using Data-Driven Models, a Case Study Abu-Ziriq Marsh in South of Iraq. Hydrology, 6, 24. https://doi.org/10.3390/hydrology6010024

[56] Chea, S. and Oeurng, C. (2017) Flow Simulation in an Ungauged Catchment of Tonle Sap Lake Basin in Cambodia: Application of the HEC-HMS Model. Water Utility Journal, 17, 3-17. https://doi.org/10.1016/j.envsoft.2013.03.006

[57] Halwatura, D. and Najim, M.M.M. (2013) Application of the HEC-HMS Model for Runoff Simulation in a Tropical Catchment. Environ. Model. Environmental Modelling \& Software, 46, 55-162. https://doi.org/10.1016/j.envsoft.2013.03.006

[58] Arnold, J.G., Srinivasan, R., Muttiah, R.S. and Williams J.R., (1998) Large Area Hydrologic Modeling and Assessment Part I: Model Development. Journal of the American Water Resources Association, 34, 73-89. https://doi.org/10.1111/j.1752-1688.1998.tb05961.x

[59] Ali, M., Khan, S.J., Aslam, I. and Khan, Z. (2011) Landscape and Urban Planning Simulation of the Impacts of Land-Use Change on Surface Runoff of Lai Nullah Basin in Islamabad, Pakistan. Landscape and Urban Planning, 102, 271-279. https://doi.org/10.1016/j.landurbplan.2011.05.006

[60] Gebre, S.L. (2015) Application of the HEC-HMS Model for Runoff Simulation of Upper Blue Nile River Basin. Hydrology Current Research, 6, 1-8. https://doi.org/10.4172/2157-7587.1000199

[61] Paul, M. (2016) Impacts of Land Use and Climate Changes on Hydrological Processes in South Dakota Watersheds.

[62] Bhuiyan, H., Mcnairn, H., Powers, J. and Merzouki, A. (2017) Application of HEC-HMS in a Cold Region Watershed and Use of RADARSAT-2 Soil Moisture in Initializing the Model. Hydrology, 4, 9. https://doi.org/10.3390/hydrology4010009

[63] Werren, G., Reynard, E., Lane, S.N. and Balin, D. (2016) Flood Hazard Assessment and Mapping in Semi-Arid Piedmont Areas: A Case Study in Beni Mellal, Morocco. Natural Hazards, 81, 481-511. https://doi.org/10.1007/s11069-015-2092-0

[64] Brirhet, H. and Benaabidate, L. (2016) Comparison of Two Hydrological Models (Lumped and Distributed) Aver a Pilot Area of the Issen Watershed in the Souss Basin, Morocco. European Scientific Journal, 12, 347-358. https://doi.org/10.19044/esj.2016.v12n18p347

[65] Khaddor, I., Achab, M. and Alaoui, A.H. (2016) Hydrological Simulation (Rainfall-Runoff) of Kalaya Watershed (Tangier, Morocco) Using Geo-Spatial Tools. Journal of Water Sciences \& Environment Technologies, 2016, 10-14. 
[66] Seif-Ennasr, M., et al. (2016) Climate Change and Adaptive Water Management Measures in Chtouka Aï Baha Region (Morocco). Science of the Total Environment, 573, 862-875. https://doi.org/10.1016/j.scitotenv.2016.08.170

[67] Fleming, M. and Neary, V. (2004) Continuous Hydrologic Modeling Study with the Hydrologic Modeling System. Journal of Hydrologic Engineering, 9, 175-183. https://doi.org/10.1061/(ASCE)1084-0699(2004)9:3(175)

[68] Tramblay, Y. (2012) Modelisation Des Crues Dans Le Bassin Du Barrage Makhazine, Maroc.

[69] Skhakhfa, I.D. and Ouerdachi, L. (2016) Hydrological Modelling of Wadiressoul Watershed, Algeria, by HEC-HMS Model. Journal of Water and Land Development, 31, 139-147. https://doi.org/10.1515/jwld-2016-0045

[70] Kowalik, T. and Walega, A. (2015) Estimation of CN Parameter for Small Agricultural Watersheds Using Asymptotic Functions. Water, 7, 939-955.

https://doi.org/10.3390/w7030939 